$\mathrm{DE}$

M E D I C I N A

T R O P I C A L

$\mathrm{DE}$

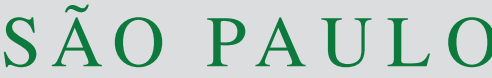

JOURNAL OF THE SÃO PAULO INSTITUTE OF TROPICAL MEDICINE

(1) Universidade Federal do Maranhão, Programa de Pós-Graduação em Saúde e Ambiente, São Luís, Maranhão, Brazil

(2)Universidade Federal do Maranhão, Programa de Pós-Graduação em Biotecnologia da Rede Renorbio, São Luís, Maranhão, Brazil

(3)Universidade Federal do Maranhão, Departamento de Farmácia, São Luís, Maranhão, Brazil

(4)Universidade Estadual do Maranhão, Departamento de Química e Biologia, São Luís, Maranhão, Brazil

Correspondence to: Luciana Patrícia Lima Alves Pereira

Universidade Federal do Maranhão, Programa de Pós-Graduação em Saúde e Ambiente, Praça da Madre Deus, ํㅡㄴ Pavilhão Pedagógico, Bairro da Madre Deus, CEP 65025-560, São Luís, MA, Brazil

Tel: +98 98845-9020

E-mail: Ilucianapatricia@yahoo.com.br

Received: 4 July 2017

Accepted: 11 September 2017

\section{Molluscicidal effect of Euphorbia umbellata (Pax) Bruyns latex on Biomphalaria glabrata, Schistosoma mansoni host snail}

\author{
Luciana Patrícia Lima Alves Pereira ${ }^{1,2}$, Clarice Noleto Dias ${ }^{1}$, Milena Valadar \\ Miranda', Wellyson da Cunha Araújo Firmo', Carliane dos Santos Rosa ${ }^{3}$, \\ Priscila Freitas Santos ${ }^{3}$, Maria Cristiane Aranha Brito ${ }^{2}$, Fernanda Oliveira \\ Sousa Araruna ${ }^{2}$, Felipe Bastos Araruna ${ }^{2}$, Nêuton Silva-Souza ${ }^{4}$, Denise \\ Fernandes Coutinho',2,3
}

\begin{abstract}
Euphorbia umbellata (Pax) Bruyns is an easily cultivated shrub, with occurrence in the tropical regions of the American and African continents. Chemical studies have revealed that the latex of this plant is rich in terpene compounds, which are highly toxic to snails Biomphalaria glabrata (Basommatophora: Planorbidae). The aim of this study was to evaluate the chemical composition and molluscicidal activity of the latex produced by E. umbellata, as well as the safety of its application in aquatic environments. The concentration of latex that killed $90 \%$ of the exposed snails after $24 \mathrm{~h}$ exposure $\left(\mathrm{LC}_{90}\right)$ was $3.69 \mathrm{mg} / \mathrm{L}$. Toxicity bioassays using Danio rerio (zebrafish) revealed that these animals were less susceptible to latex than planorbids. However, it is important to perform other toxicity tests to ensure the feasibility of using latex to control populations of mollusks that contribute to schistosomiasis transmission. A phytochemical screening performed with the E. umbellata latex identified the triterpenoid and coumarin class. Further studies are warranted to isolate, identify, and test the active compounds of E. umbellata latex in B. glabrata.
\end{abstract}

KEYWORDS: Plant product. Toxicity. Biomphalaria glabrata. Schistosomiasis. Schistosoma mansoni. Molluscicidal effect.

\section{INTRODUCTION}

Schistosomiasis is a parasitic disease associated with poverty and low economic development, prevalent in 54 countries in Africa, Asia, and South America ${ }^{1}$. In Brazil, it is considered one of the most serious public health issues due to its significant propagation potential ${ }^{2}$. Schistosomiasis has been identified in 19 of the 27 federal units of the country, with an endemic area extending from Maranhão to Espírito Santo and Minas Gerais ${ }^{3}$.

Schistosomiasis develops after contact with larvae of the Schistosoma mansoni Sambon parasite, which are released from host snails in freshwater environments. Three species of Biomphalaria mollusks transmit S. mansoni in Brazil. Biomphalaria glabrata (Say, 1818) species stands out as the main intermediate host in the Americas, as it is associated with high levels of infection and has a geographical distribution that mostly coincides with the occurrence of schistosomiasis ${ }^{4}$.

The use of molluscicide products in regions of increased schistosomiasis transmission is one of the strategies employed to combat this parasitosis. The 
synthetic molluscicide niclosamide is widely used in natural sites of the snails. However, this chemical product has a low degradation capacity in the environment and is toxic to non-target organisms ${ }^{5}$. Due to this limitation of niclosamide, the current schistosomiasis control campaigns in Brazil have been limited to the diagnosis of schistosomiasis and subsequent treatment with the drug praziquantel. Although these clinical measures are important, they must be combined with vector control using substances that have molluscicide properties. This would effectively interrupt $S$. mansoni life cycle and, consequently, reduce the number of new infections or re-infections.

Plant molluscicides are a low-cost, biodegradable, safe alternative to the use of niclosamide ${ }^{6}$. The number and diversity of plants that are toxic to mollusks are high, especially among species of the Euphorbiaceae family ${ }^{7}$.

The species Euphorbia umbellata (Pax) Bruyns (synonyms Synadenium umbellatum Pax and Synadenium grantii Hook) is commonly known as "glue-note," "avelos," "miraculous," or "cancerola". This plant is an easily cultivated shrub, with oval leaves, short petioles, and dark red flowers ${ }^{9}$. It is native to Africa and cultivated in the tropical regions of the American and African continents ${ }^{10}$.

Phytochemical studies showed that $E$. umbellata latex is rich in proteolytic enzymes, glycoproteins, lectins, and terpenes ${ }^{11-15}$. Among these compounds, the terpene class has shown high molluscicide potential in B. glabrata $^{16,17}$. Therefore, considering the importance of research and development of new natural products for the control of mollusks that contribute to schistosomiasis transmission, and the presence of molluscicides chemical compounds in E. umbellata latex, we aimed to evaluate the toxicity of this plant product in B. glabrata adult snails.

\section{MATERIAL AND METHODS}

\section{Plant product}

E. umbellata latex was collected in June 2012, from longitudinal incisions in the stems of specimens cultivated in the garden of medicinal plants at the Federal University of Maranhão, Bacanga Campus (2³8'07''S; 4419'16'W), located in São Luís, Maranhão, Brazil. The plant species was identified and a dried specimen was deposited in the Atico Seabra Herbarium of the UFMA, under the catalog $\mathrm{N}^{\circ}$ HSLZ-01212.

\section{Molluscicidal activity assay}

The molluscicidal activity assay was performed in B. glabrata, in accordance with the standards of the
World Health Organization ${ }^{18}$. Snails were collected in the district of Sá Viana (2³3'30.38"S; 44¹8'12.46”W), in São Luís, and housed in the laboratory for species identification and detection of potential $S$. mansoni infection. Groups of ten B. glabrata adult snails, with shell of 10-19 mm diameter and free of S. mansoni infection, were exposed to latex solutions with concentrations ranging from 0.5 to $100 \mathrm{mg} / \mathrm{L}$. Each concentration was assessed in triplicate. Snails of the control group were kept in dechlorinated water. The snails were kept in different solutions for $24 \mathrm{~h}$ at room temperature. After exposure, snails were washed, transferred to containers with $500 \mathrm{~mL}$ of dechlorinated water, fed with lettuce leaves and observed for four days to assess mortality. Mortality was identified by shell discoloration, full retraction of the cephalopodal mass into the shell, loss of muscle contraction, hemolymph release, and deterioration of the cephalopodal mass.

\section{Toxicity bioassay}

To investigate the possible action of latex in organisms that live in the natural habitat of B. glabrata, we conducted tests with adult Danio rerio (zebrafish) specimens, according to the methodology described in the Brazilian Association of Technical Standards ${ }^{19}$. Groups of four zebrafish were placed in glass containers with latex dilutions, at a ratio of 1 gram of zebrafish to a liter of test solution. The effect of test solutions was evaluated in quadruplicates over $48 \mathrm{~h}$ in concentrations ranging from 0.5 to $14 \mathrm{mg} / \mathrm{L}$. Every $24 \mathrm{~h}$, we counted the number of dead animals and measured variables such as $\mathrm{pH}$, conductivity, dissolved oxygen and temperature, without replacing the solutions. The negative control group was represented by zebrafish kept in dechlorinated water. Both the molluscicidal activity test and the toxicity bioassay with $D$. rerio were performed according to the principles of animal welfare in experimental science.

\section{Phytochemical screening}

Classes of secondary metabolites that were possibly responsible for the molluscicidal action of $E$. umbellata latex were identified through a phytochemical screening, which was carried out according to the methodology proposed by Matos $^{20}$. Diluted latex was subjected to several tests to identify phenols and tannins (reaction with ferric chloride), flavonoids ( $\mathrm{pH}$ variation test with sodium hydroxide and sulfuric acid), steroids and triterpenoids (LiebermannBurchard test), saponins (foam test), coumarins (UV light test), and alkaloids (identification with Dragendorff, Hager and Mayer). 


\section{Statistical analysis}

The evaluation of molluscicidal activity and latex toxicity was performed by calculating the lethal concentrations $\left(\mathrm{LC}_{10}, \mathrm{LC}_{50}\right.$, and $\left.\mathrm{LC}_{90}\right)$. The $\mathrm{LCs}$ were determined by probit analysis using the SPSS 13.0 software.

\section{RESULTS AND DISCUSSION}

The E. umbellata latex showed high toxicity in B. glabrata adult snails after $24 \mathrm{~h}$ exposure. No dead mollusk was observed in the negative control group throughout the experiment. Latex $\mathrm{LC}_{10}, \mathrm{LC}_{50}$ and $\mathrm{LC}_{90}$ values, as well as their respective $95 \%$ confidence intervals, are shown in Table 1.

The effect of the alcoholic extract of E. umbellata leaves on B. glabrata was studied by Hartmann et al. ${ }^{21}$, who reported an $\mathrm{LC}_{50}$ of $40 \mathrm{mg} / \mathrm{L}$. In our study, the $\mathrm{LC}_{50}$ of E. umbellata latex was $1.36 \mathrm{mg} / \mathrm{L}$. These results indicate that this product is highly toxic to mollusks.

Latex of other species of the Euphorbia genus has also shown molluscicide potential in B. glabrata. An aqueous solution of latex of Euphorbia tirucalli L., a plant commonly known as "avelos" had an $\mathrm{LC}_{90}$ of $85 \mathrm{mg} / \mathrm{L}$ in B. glabrata $^{22}$. Latex of Euphorbia conspicua L. was highly toxic to these snails, with an $\mathrm{LC}_{90}$ of $4.87 \mathrm{mg} / \mathrm{L}^{23}$.

The mechanism by which aqueous latex solutions cause the death of these snails is not completely known. However, in this work, we observed retraction of the cephalopodal mass followed by hemolymph release in the planorbids that were killed by the tested latex. According to McCullough et al. ${ }^{24}$, molluscicides generally cause impairment of the osmotic balance in mollusks, which is under neurohormonal control. Consequently, two mechanisms could explain the death of snails: the cephalopodal mass is retracted into the shell with subsequent hemolymph release or the cephalopod is projected out of the shell in an unusual way.

According to the World Health Organization ${ }^{25}$, a product is considered molluscicide when its $\mathrm{LC}_{90}$ or $\mathrm{LC}_{100}$ is below $100 \mathrm{mg} / \mathrm{L}$. Considering this criterion, E. umbellata latex, which had an $\mathrm{LC}_{90}$ of $3.69 \mathrm{mg} / \mathrm{L}$ in $24 \mathrm{~h}$, represents a feasible alternative strategy to control schistosomiasis in endemic areas of Brazil. Furthermore, this latex is biodegradable, inexpensive and obtained from renewable resources.

Danio rerio, commonly known as zebrafish, has omnivorous feeding habits and can be easily bred under artificial conditions ${ }^{26}$. This species has been used to assess the toxic effects of latex of Euphorbia splendens var. hislopii ${ }^{27}$. In the present study, assays with $D$. rerio were performed to investigate the toxicity of $E$. umbellata latex in non-target organisms. The concentration that killed $90 \%$ of the fish $\left(\mathrm{LC}_{90}\right)$ was $10.70 \mathrm{mg} / \mathrm{L}$ (Table 1), which is higher than the $\mathrm{LC}_{90}$ in the molluscicidal bioassay. However, it is important to perform other toxicity tests using Artemia salina, tadpoles and the fish Poecilia reticulata to ensure that the application of latex in natural environments does not cause damage to organisms that cohabitate with mollusk disease-transmitters.

Phytochemical profile information not only facilitate the study of a plant material, but also direct research related to the use of this material for different purposes, such as the production of new drugs and antibiotics, contributing to the research of molluscicidal substances of plants ${ }^{28}$. In the phytochemical study carried out with $E$. umbellata latex the metabolites phenols, tannins, flavonoids, steroids, saponins and alkaloids were not detected. Although saponins have not been verified in the studied sample, these polar chemical substances have high toxicity in snails and are considered excellent molluscicidal agents.

In the Liebermann-Burchard test, after addition of $1 \mathrm{~mL}$ of acetic anhydride and three drops of concentrated $\mathrm{H}_{2} \mathrm{SO}_{4}$ to the latex, the presence of triterpenes was detected in low concentrations, indicated by the change from white to red color of the latex. Previous studies have verified triterpenes in latex of other Euphorbia species ${ }^{29,30}$. Triterpenes are compounds commonly found in nature and difficult to isolate when conventional chromatographic techniques are employed. Most of the time, these chemical constituents are obtained in mixtures of difficult analysis ${ }^{31}$.

Coumarins in small concentrations in the latex were detected by the formation of strong bluish fluorescence under UV light. Despite the achievement of this result,

Table 1 - Toxicity of the latex from Euphorbia umbellata (Pax) Bruyns

\begin{tabular}{lccc}
\hline $\begin{array}{l}\text { Tested Organisms } \\
\text { Snails }\end{array}$ & $\begin{array}{c}\mathrm{LC}_{10} \\
(95 \% \mathrm{Cl})\end{array}$ & $\begin{array}{c}\mathrm{LC}_{50} \\
\left(95 \% \mathrm{Cl}^{\mathrm{a}}\right)\end{array}$ & $\begin{array}{c}\mathrm{LC}_{90} \\
\left(95 \% \mathrm{Cl}^{\mathrm{a}}\right)\end{array}$ \\
\hline $\begin{array}{l}\text { Biomphalaria glabrata } \\
\text { Adults }\end{array}$ & $0.50(0.110-0.871)$ & $1.36(0.716-1.815)$ & $3.69(2.832-6.217)$ \\
Danio rerio (zebrafish) & $4.86(3.233-5.841)$ & $7.22(6.096-8.053)$ & $10.70(9.473-13.470)$ \\
\hline
\end{tabular}

${ }^{\mathrm{a}} \mathrm{Cl}=$ Confidence interval. 
no records were found in the literature on the presence of coumarins in resins. However, this metabolite class has molluscicidal action. Gasparotto-Júnior et al. ${ }^{32}$ isolated a coumarin, called (-) mammea $\mathrm{A} / \mathrm{BB}$, from leaves of the plant Calophyllum brasiliense Camb., popularly known as guanandi. The assay with B. glabrata revealed that the isolated coumarin was highly toxic, exhibiting a $\mathrm{CL}_{90}$ de $1.47 \mathrm{mg} / \mathrm{L}$.

Further studies are necessary to isolate and identify the active compounds present in the latex and to test these substances in B. glabrata mollusks.

\section{ACKNOWLEDGMENTS}

We would like to thank the Federal University of Maranhão and the Foundation of Support for Research and Scientific and Technological Development of Maranhão (FAPEMA) for their financial support.

\section{CONFLICTS OF INTEREST}

The authors declare no conflicts of interest.

\section{REFERENCES}

1. Rocha TJ, Santos MC, Lima MV, Calheiros CM, Wanderley FS. Aspectos epidemiológicos e distribuição dos casos de infecção pelo Schistosoma mansoni em municípios do estado de Alagoas, Brasil. Rev Pan-Amaz Saúde. 2016;7:27-32.

2. Cardim LL, Ferraudo AS, Pacheco ST, Reis RB, Silva MM, Carneiro DD, et al. Análises espaciais na identificação das áreas de risco para a esquistossomose mansônica no Município de Lauro de Freitas, Bahia, Brasil. Cad Saúde Pública. 2011;27:899-908.

3. Barreto AV, Melo ND, Ventura JV, Santiago RT, Silva MB. Análise da positividade da esquistossomose mansoni em regionais de saúde endêmicas em Pernambuco, 2005 a 2010. Epidemiol Serv Saúde. 2015;24:87-96.

4. Brasil. Ministério da Saúde. Secretaria de Vigilância em Saúde. Departamento de Vigilância Epidemiológica. Vigilância da Esquistossomose Mansoni: diretrizes técnicas. $4^{\mathrm{a}}$ ed. Brasília: Ministério da Saúde; 2014.

5. Lopes TC, Gonçalves JR, Souza NS, Moraes DF, Amaral FM, Rosa IG. Avaliação moluscicida e perfil fitoquímico das folhas de Caryocar brasiliense Camb. Cad Pesq. 2011;18:23-30.

6. Oliveira-Filho EC, Geraldino BR, Coelho DR, De-Carvalho RR, Paumgartten FJ. Comparative toxicity of Euphorbia milii latex and synthetic molluscicides to Biomphalaria glabrata embryos. Chemosphere. 2010;81:218-27.

7. Moreira CP, Zani CL, Alves TM. Atividade moluscicida do látex de Synadenium carinatum Boiss. (Euphorbiaceae) sobre
Biomphalaria glabrata e isolamento do constituinte majoritário. Rev Eletron Farm. 2010;8:16-27.

8. Valadares MC, Castro NC, Cunha LC. Synadenium umbellatum: citotoxicidade e danos ao DNA de células da medula óssea de camundongos. Rev Bras Cienc Farm. 2007;43:631-8.

9. Costa LL, David VC, Pinto RM, Minozzo BR, Kozlowski Jr VA, Campos LA, et al. Anti-ulcer activity of Synadenium grantii latex. Rev Bras Farmacogn. 2012;22:1070-8.

10. Cunha LC, Azeredo FS, Mendonça AC, Vieira MS, Pucci LL, Valadares MC, et al. Avaliação da toxicidade aguda e subaguda, em ratos, do extrato etanólico das folhas e do látex de Synadenium umbellatum Pax. Rev Bras Farmacogn. 2009;19:403-11.

11. Menon M, Vithayathil PJ, Raju SM, Ramadoss CS. Isolation and characterization of proteolytic enzymes from the latex of Synadenium grantii Hook, 'f'. Plant Sci. 2002;163:131-9.

12. Rajesh R, Nataraju A, Gowda CD, Frey BM, Frey FJ, Vishwanath BS. Purification and characterization of a 34-kDa, heat stable glycoprotein from Synadenium grantii latex: action on human fibrinogen and fibrin clot. Biochimie. 2006;88:1313-22.

13. Premaratna A, Shdaksharaswamy M, Nanjappa S. Some biological properties of Synadenium grantii lectin. Indian J Pathol Microbiol. 1984;27:91-7.

14. Bagavathi R, Sorg B, Hecker E. Tigliane-type diterpene esters from Synadenium grantii. Planta Med. 1988;54:506-10.

15. Uzabakiliho B, Largeau C, Casadevall E. Latex constituents of Euphorbia candelabrum, E. grantii, E. tirucalli and Synadenium grantii. Phytochemistry. 1987;26:3041-5.

16. Baloch IB, Baloch MK, Baloch AK. Schistosomiasis suppressing deoxyphorbol esters from Euphorbia cauducifolia L. latex. Planta Med. 2010;76:809-14.

17. Mata RC, Mendonça DI, Vieira L, Santos AF, Silva LA, Gaspar JF, et al. Molluscicidal activity of compounds isolated from Euphorbia conspicua N. E. Br. J Braz Chem Soc. 2011;22:1880-7.

18. World Health Organization. Molluscicide screening and evaluation. Bull World Health Organ. 1965;33:567-81.

19. Associação Brasileira de Normas Técnicas. NBR 15088:2016 ecotoxicologia aquática - toxicidade aguda - método de ensaio com peixes (Cyprinidae). Rio de Janeiro: ABNT; 2016.

20. Matos FJ. Introdução à fitoquímica experimental. $3^{\mathrm{a}}$ ed. Fortaleza: UFC; 2009.

21. Hartmann DB, Marim RA, Silva YL, Zardeto G, Silva IA, Mattos DA, et al. Letalidade do extrato de Synadenium grantii Hook. F. (Euphorbiaceae) frente a caramujos Biomphalaria glabrata Say, 1818 (Gastropoda, Planorbidae). Arq Cienc Vet Zool UNIPAR. 2011;14:5-11.

22. Jurberg P, Cabral Neto JB, Schall VT. Molluscicide activity of the "avelós" plant (Euphorbia tirucalli L.) on Biomphalaria glabrata, the mollusk vector of schistosomiasis. Mem Inst Oswaldo Cruz. 1985;80:423-7. 
23. Santos AF, Azevedo DP, Mata RC, Mendonça DI, Sant'Ana AE. The lethality of Euphorbia conspicua to adults of Biomphalaria glabrata, cercaria of Schistosoma mansoni and larvae of Artemia salina. Bioresour Technol. 2007;98:135-9.

24. McCullough FS, Gayral PH, Duncan J, Christie JD. Molluscicides in schistosomiasis control. Bull World Health Organ. 1980;58:681-9.

25. World Health Organization. Report of the scientific working group on plant molluscicides. Geneva: WHO; 1983.

26. Silva BM, Ravaneli MA, Paschoalato CF. Toxicidade aguda dos herbicidas diuron e hexazinona à Danio rerio. Pesticidas. 2010;20:17-28.

27. Oliveira-Filho EC, Paumgartten FJ. Toxicity of Euphorbia milii latex and niclosamide to snails and nontarget aquatic species. Ecotoxicol Environ Saf. 2000;46:342-50.

28. Pereira Filho AA, França CR, Oliveira DS, Mendes RJ, Gonçalves JR, Rosa IG. Evaluation of the molluscicidal potential of hydroalcoholic extracts of Jatropha gossypiifolia Linnaeus,
1753 on Biomphalaria glabrata (Say, 1818). Rev Inst Med Trop Sao Paulo. 2014;56:505-10.

29. Koops AJ, Baas WJ, Groeneveld HW. The composition of phytosterols, latex triterpenols and wax triterpenoids in the seedling of Euphorbia lathyris L. Plant Sci. 1991;74:185-91.

30. Fernandez-Arche A, Saenz MT, Arroyo M, de la Puerta R, Garcia MD. Topical antiinflammatory effect of tirucallol, a triterpene isolated from Euphorbia lactea latex. Phytomedicine. 2010;17:146-8.

31. Maia RM, Barbosa PR, Cruz FG, Roque NF, Fascio M. Triterpenos da resina de Protium heptaphyllum March (Bourseraceae): caracterização em misturas binárias. Quim Nova. 2000;23:6236.

32. Gasparotto Jr A, Brenzan MA, Piloto IC, Cortez DA, Nakamura CV, Dias Filho BP, et al. Estudo fitoquímico e avaliação da atividade moluscicida do Calophyllum brasiliense Camb (Clusiaceae). Quim Nova. 2005;28:575-8. 